\title{
Local Political Leadership in Portugal: Excepcionalism or Convergence Towards a 'Mayoral Model'?
}

\author{
CARLOS NunES SILVA
}

\begin{abstract}
The purpose of this paper is to examine the reform of institutional forms that frame local government in Portugal, and to put them into a comparative European perspective. The paper addresses the following research question: To what extent have Portuguese local government reforms shown convergence or divergence with the local political leadership models in Europe over the last three decades of democracy? We hypothesized that reforms affected the local government system in different ways, using some of its components and following more explicitly international trends than others. This hypothesis was tested against the model of local political leadership, including the rules governing the recruitment of mayors and local councillors. This study is based on both archival research for the Portuguese case and the literature review for the survey of international trends. The findings indicate the existence of similarities between reforms in Portugal and reforms in other European countries. But they also indicate divergence in some important dimensions of the local government system.
\end{abstract}

KEYWORDS: - local government reform • institutional forms • recruitment $\bullet$ models of local political leadership $\bullet$ Portugal

Correspondence AdDress: Carlos Nunes Silva, Ph.D., Department of Geography, Edifício da Faculdade de Letras, University of Lisbon, Alameda da Universidade, 1600-214 Lisbon, Portugal, e-mail: cnsilva@fl.ul.pt. 


\section{Introduction}

Local government systems differ across and between European countries due to different historical processes and political traditions, which in part explains the way each national system is adapted to the economic and social changes that have occurred in the last few decades. In his comparative analysis of four countries (France, England, Germany and Sweden), Wollmann (2004) found evidence in support of the 'convergence thesis' on several scores: a trend towards the strengthening of political institutions in local government and the reinforcement of democratic participatory rights for local citizens; a trend towards decentralisation; and the introduction of managerialist principles. However, the same study shows that in a number of other dimensions there is a persistent divergence, and, in some cases, it seems to be increasing. Similar conclusions have been reached by other authors exploring other issues. For example, Michael Goldsmith (2004) highlights the increasing importance of informal means of central government control over local government as compared to the traditional formal control, a trend that seems to cross all European countries, enhanced by the procedures of the European Union policies, but in quite different ways according to the national specific historical and cultural traditions. Berg et al. (2005), Leach et al. (2005), Haus and Sweeting (2006) and Vogelsang-Coombs (2007), among others, identified and described numerous models of local political leadership in the European countries and, more recently, the development of a trend towards the strengthening of the Mayor's role either through direct election or simply by strengthening his/her powers vis-à-vis the other members of the executive board.

The present local political system in Portugal was institutionalized in the 1976 democratic Constitution adopted two years after the fall of the authoritarian regime that lasted from 1926 to 1974 . The 1976 Constitution defined three tiers of sub-national self-government: the parish ('freguesia') - a lower level of local government; the municipality ('município'); and the administrative region ('região administrativa') - the upper level of local government that has not yet been implemented. The Constitution defines broad principles similar to the three tiers of local government, but the subsequent legislation has maintained the parish (4260 parishes in 2008) with very limited capacities compared to the municipality (308 municipalities in 2008) which, besides having a broader scope of tasks and responsibilities, has also a greater financial capacity.

The municipality has two political bodies: the Municipal Assembly ('assembleia municipal') with deliberative powers, and the Municipal Council ('câmara municipal'). Both of them are elected via a closed list system by universal, direct and secret suffrage in accordance with the principle of proportional representation for a four-year term. Party groups in the Municipal Council as well as in the Assembly, where they are organised as parliamentary groups, usually act and vote as a block. There is a separation of powers between the Municipal Council, 
comprising the Mayor, and the Assembly. The Mayor is the head of the administration, charged with ensuring that the political decisions taken by the Municipal Council and Assembly are implemented.

The number of the Municipal Council members varies according to the number of electors of the municipality (Table 1). The Mayor and those councillors that have direct functional responsibilities ('pelouro') work full time or half time (Table 2), earning a percentage of the salary of the President of the Republic (Table 3). The remaining councillors can benefit from a reduction of up to 32 hours of service in their employment plus from subsidies to cover costs of his or her participation in the Council meetings.

Due to the proportional voting system adopted in the elections to both bodies, different political parties, and since 2001, non-partisan lists may have also been represented in the Municipal Council. Owing to this very rule there is a possibility that the political list headed by the Mayor has no overall majority in the Municipal Council and/or in the Assembly.

Table 1: Number of members of the municipal councils (executive and deliberative bodies)*

\begin{tabular}{|c|c|c|}
\hline $\begin{array}{l}\text { Categories of } \\
\text { municipalities } \\
\text { (by number of } \\
\text { electors) }\end{array}$ & $\begin{array}{c}\text { Number of } \\
\text { Municipal } \\
\text { Council } \\
\text { members } \\
\text { (Câmara } \\
\text { Municipal)** }\end{array}$ & $\begin{array}{l}\text { Number of Municipal Assembly members } \\
\text { (Assembleia Municipal) }\end{array}$ \\
\hline Lisbon & 17 & $\begin{array}{l}\text { Municipal Assembly comprises directly elected } \\
\text { members and the Parish Chairmen ('Junta de } \\
\text { Freguesia'). }\end{array}$ \\
\hline Porto & 13 & rieguesta ) \\
\hline$\geq 100000$ & 11 & $\begin{array}{l}\text { The number of the Assembly members is determined } \\
\text { according to the following norms: }\end{array}$ \\
\hline $\begin{array}{l}>50000 \ldots< \\
100000\end{array}$ & 9 & i) - all Parish Council chairmen; \\
\hline $\begin{array}{l}>\quad 10000 \quad \cdots \\
50000\end{array}$ & 7 & $\begin{array}{l}\text { ii) - the minimum number of elected members is three } \\
\text { times the number of Municipal Council members; }\end{array}$ \\
\hline$\leq 10000$ & 5 & $\begin{array}{l}\text { iii) - the elected members should be at least one more } \\
\text { than the number of the Parish Council chairmen. }\end{array}$ \\
\hline
\end{tabular}

Source: own elaboration, based on Law 169/99, 18-9-1999, revised by Law 5-A/2002, 11-1-2002.

* - Between 1976 and 1982 there was a consultative body whose implementation was compulsory. It was composed of social, economic and cultural local stakeholders and had only consultative powers and could in no way change any decision of the other two bodies. The 1982 Constitutional revision 
made its implementation optional due to the fact that in most cases, it had no practical relevance, being abolished in the 1989 Constitutional revision.

** - These figures comprise the Mayor (i.e., in Lisbon, 16 councillors plus the Mayor / Municipal Council chairman).

\section{Table 2: Number of full-time councillors in the Municipal Council}

\begin{tabular}{|l|l|}
\hline $\begin{array}{l}\text { Categories of municipalities (by } \\
\text { number of electors) }\end{array}$ & $\begin{array}{l}\text { Municipal Council } \\
\text { (number of full-time councillors)* }\end{array}$ \\
\hline Lisbon \& Porto & 4 \\
\hline$\geq 100000$ & 3 \\
\hline$>20000 \ldots<100000$ & 2 \\
\hline$\leq 20000$ & 1 \\
\hline
\end{tabular}

Source: own elaboration, based on Law 169/99, 18-9-1999, revised by Law 5-A/2002, 11-1-2002.

* - The Mayor is always employed full-time. These figures do not include the Mayor. Upon the proposal of the Mayor and by the decision of the Municipal Council, the number can be higher. One full-time councillor corresponds to two half-time councillors. It is a competence of the Mayor to choose which councillors will be employed full-time or half-time. The councillors who are employed neither full-time nor half-time can benefit from their working reduction up to 32 hours per month (the employer is compensated for the costs associated with the use of this right).

Table 3: Salary of the Mayor and full-time councillors in the Municipal Council*

\begin{tabular}{|l|l|l|}
\hline $\begin{array}{l}\text { Categories of } \\
\text { municipalities (by number } \\
\text { of electors) }\end{array}$ & $\begin{array}{l}\text { Salary of the Mayor } \\
(\% \text { salary President of } \\
\text { the Republic**) }\end{array}$ & $\begin{array}{l}\text { Salary of full-time } \\
\text { councillors*** } \\
(\% \text { salary Mayor })\end{array}$ \\
\hline Lisbon \& Porto & 55 & \multirow{2}{*}{80} \\
\hline$\geq 40000$ & 50 & \\
\hline$>10000 \ldots<40000$ & 45 & \\
\hline Other & 40 &
\end{tabular}

Source: own elaboration, based on Law 29/87, 30 June.

* - If not in exclusivity, the Mayor or councillor receive only $50 \%$ of the full salary.

** - Salary of the President of the Republic (in 2007) = EUR 6897.94

$* * *$ - Half-time councillors receive half of the salary of a full-time councillor.

\section{$2 \quad$ Leadership and Political Recruitment}

Local political leadership models or institutional forms are essentially structures and norms that shape the behaviour of mayors and local councillors and their leadership style. They are the framework within which local political actors choose their courses of actions, as Back (2005) and others argue, but do not determine them. In most cases, the result is a diversity of practices within the same institutional model or institutional forms. 
The way each model functions is also dependent, as Stone (2005) and others argue, on the local political culture, on how leaders interpret their role, on the existence or not of a political majority, on the socio-economic and demographic characteristics of the local community, on the specific national institutional context, on the level of functional and political devolution, on the welfare/gender regime (Johansson, 2006) and on other contextual factors (Goldsmith et al., 2004; Hambleton et al., 2004; Wollmann, 2004), especially when there is evidence that suggests the existence of a shift from traditional and hierarchical forms of urban administration to a model of urban governance based mainly on networks (Gissendanner, 2004; Denters et al., 2005; Gabriel et al., 2005; Rose et al., 2005) and on 'quangoization' of local government (Wollmann, 2004) which, in some cases, is seen as a process that undermines democracy and local political accountability (Geddes, 2006).

In practice, each leadership model is also affected by the relationship between the Mayor and his/her political party. The evidence available suggests that, whatever the model, direct or indirect election of the Mayor, such relation is variable depending on the type of government, electoral system and local context, as Fallend et al. (2006) argue, on the size of the municipality and on personal characteristics, conditions that Hambleton et al. (2004) also found when comparing UK and US local government systems.

Notwithstanding the diversity of political leadership models, reforms since the late 1990's, in several European countries, privileged institutional models based on direct mayoral election (Borraz et al., 2004; Fenwick et al., 2006; Magre et al., 2007), in some places, a response to the legitimacy crisis associated with lower electoral turnouts (Kjaer, 2007; Kolk, 2007) or, as Borraz et al. (2004: 107) point out, a "functional response to the complex character of networks", a reflex of changing elite and citizens' values, an institutional mimetic phenomenon, or an answer to the increasingly powerful European Union. Directly elected mayors are expected to have a leadership style less dependent on the political party compared to the situation in which they are initially chosen by the party members in the local party assembly.

In Portugal, contrary to this general European trend, the executive power lies, since the 1976 Constitution, in the Municipal Council as a whole and, therefore, collegiality is formally the principle that governs the decision making process. However, in practice, the Mayor is widely recognised as the key actor in the municipal political system and in this sense, she/he is the person that is held politically responsible more than the collective board and more than anyone else. In some cases, the Mayor has full control in relation to the constitution of the list before the election, and can afterwards take away the authority delegated to one or more councillors but, within the present legal framework, cannot replace them. 
The role of the Mayor is pivotal for the entire system. Since the Mayor has a guidance role inside and outside the Municipal Council, he or she is in control of the decision-making system and fulfils a number of essential political and administrative functions. The law gives the Mayor several competences, such as agenda setting, including the definition of policy priorities, implementation of decisions, management of municipal assets, responsibilities over the staff, municipal budget preparation, external representation, authority over the municipal police force, etc. However, his or her leadership role is also affected by other contextual and contingent factors, such as the relations with what Fernandes (1993) calls "diffuse powers" (church, business associations, social, sports and cultural associations, etc.) and with the local social elites.

The way the Municipal Council is organised determines the kinds of functions in which councillors are involved, and the level of influence they will have in the final decisions. In fact, the Mayor has sufficient room for manoeuvre in order to delegate more or less power within the same model, acting as a facilitative or as a centralist leader; in the latter case, through the concentration of power and control over the main policy sectors, thus making it a system in which diversity in leadership styles is also one of its key characteristics as in other European countries.

In addition, in the Portuguese case, evidence suggests that the role of each party's central office in local affairs differs from party to party, as well as the control role of the local party over the Mayor, a factor that can influence the Mayor's leadership style. In some cases, decisions are discussed inside the party organization before they are taken within the Municipal Council, and in other cases there are regular meetings between the local party office and the party's elected Mayor and councillors. For example, according to the Socialist Party Constitution, the local party section coordinates with socialist Mayor and councillors the party's local policy. The local party executive is due to meet with the socialist councillors and Mayor at least every three months (PS, 2003).

The political decisions, taken by the Municipal Council as a whole or by each of its members, including the Mayor's decisions, are implemented by professional bureaucrats in the municipal administration departments (Law 5-A/2002, article 70). Their degree of autonomy differs because the Mayor and councillors tend to establish different kinds of relations with the departments they control, but whatever the level of the delegation of competences to chief executives (i.e., Director of Municipal Department, Chief of Service or Chief of Division), these posts depend on political trust, and the evidence suggests that they can participate in the definition of the strategies, but they are not entirely responsible for them. Consistent political majorities in the Municipal Council tend to reduce the autonomy of bureaucrats inside municipal administration. Strong mayors tend to control more and leave less room for manoeuvre for those professionals and, on 
the contrary, mayors that favour a more collective style of leadership tend to delegate more competences to other councillors and to high-ranking professionals in the municipal organization.

The general move from government to governance, expressed by the increase in the number of actors on the local political stage, of municipal enterprises and of other forms of organisation ruled by private law, tends to transform the traditional leadership role of the Mayor and has also the potential to make political control and accountability more diffuse and much less transparent, a process common to most European countries and already well developed in Portugal. In addition to this, dilution of responsibilities associated with the rise of inter-municipality means that certain actions will be decided and implemented jointly with other municipalities, a feature that gets more emphasized in those cases where the municipality participates in several associations.

In 2001, an attempt was made to change the key aspects of the local electoral law, and in that context, a change from direct to indirect election of the Municipal Council was proposed. Or in other words, it was a change somehow contrary to the prevailing trend in other parts of Europe at that time. Under that proposal ${ }^{1}$, citizens would elect the Municipal Assembly, and the Mayor would be the number one on the winning list. The other councillors would be appointed by the Mayor from among the elected members of the Assembly and would also take on personal responsibilities for specific portfolios. The aim was to have a politically uniform Municipal Council and to give the Mayor full power to handle his team (i.e., it would be possible for him to replace the Municipal Council members at any time; the Assembly could only reject this sort of proposals with $2 / 3$ of the votes).

In sum, despite the diversity of local political leadership models in Europe and the multiple factors that affect their practice, reforms have tended to reinforce the executive role of the Mayor and greater political legitimacy through the direct mayoral election over the last few decades. In Portugal, the model of collective decision making or collegiality, adopted pursuant to the 1976 Constitution, was somehow contrary to the institutional forms prevailing in many other European countries at that time. However, in practice, a series of factors gave the Mayor a much more powerful role than what was provided by law. Over the last few years, the proposals have pointed to the convergence with a mayoral model, although evidence shows that, even within the same institutional model, local contexts and personal characteristics influence the way political leadership is exercised.

On the other hand, the model of local political leadership is closely associated and dependent on political recruitment rules. Also in this case, the evidence suggests a trend towards convergence of formal procedures, although national and local specificities continue to make a difference. 
As Meadowcroft (2001), Mitchell et al. (2004), Hazan et al. (2006), Norris (2006) and others have shown, the recruitment of municipal councillors is affected by several factors in any of the local political leadership models: electoral rules (i.e., conditions of eligibility: age, citizenship, residence, etc.), party selection procedures (i.e., party membership for a specified period prior to candidacy, decision-making process regarding nomination, etc.), equal opportunities policy, positive discrimination measures, legal incompatibilities, the council service status, political tasks assigned to the Municipal Council members, the time required for public service, remuneration, perspectives for political career advancement, perceived personal costs and benefits among other reasons. And as Norris (2006) suggests, the recruitment process can have many impacts on the division of power as well as consequences for political accountability.

Traditionally, local political recruitment has been the decentralised competence of local party sections in most European countries, although with differences between parties as Katz et al. (1994), Mitchell et al. (2004), Wheeler (2006) and others point out. In practice, however, the relation with the local party section is dependent on the Mayor's personal characteristics, on the political composition of the Municipal Council, and on other factors that affect the way his/her personal leadership is expressed as has been indicated by Copus (2004), Genieys et al. (2004) and Martinussen (2004).

The application of positive actions, equal opportunities or positive discrimination strategies, aiming to mobilize politically under-represented groups, namely, women (i.e., gender parity in recruitment or quota systems) have expanded and they have an effect on recruitment processes (Dahlerup, 2007; Davidson-Schmich, 2006). Their real effect depends on the specific quota form adopted, as Geissel et al. (2005) explain in the case of Germany, on intra-party politics, on women's agency and persuasion (Threlfall, 2007), or on the "interaction between legislative measures, cultural norms and social discourse", as Holli et al. (2006: 187) argue in their analysis of the Finnish case. However, even where these measures are in place, the prevalence of traditional views of leadership among local councillors can sustain what Broussine (2002: 91) describes as «institutionalised sexism in local government». The adoption of effective sanctions for non-compliance is likely to help to achieve success in this field, as Davidson-Schmich (2006) suggests.

In the Portuguese case, the electoral law, applied from 1976 until the election of 1997, allowed only party lists in municipal elections. That norm excluded potential candidates unwilling to follow party discipline or to enter in negotiations and agreements of all sorts with the different interests present in the local party 'machine'. However, those unwilling to become a party member still had the possibility to enter the party list as an independent member, a possibility used differently by all political parties, being this percentage a little higher in the left- 
wing parties than in the right-wing ones. For the first time, non-partisan lists were allowed in the 2001 election. They obtained less than $2 \%$ of the total votes for municipal boards (1.6\% for the Municipal Council and 1.2\% for the Assembly), which led to the election of a very small number of mayors.

Local sections of political parties are also important actors in the selection of local political leaders. In some cases there are tensions between the central party and the local section over the recruitment of local candidates, a situation that can be found in different political parties, although addressed in different ways. In this context, allegations of party centralism are not rare. The recruitment of candidates for the party list in municipal elections is, in general, a competence of the local party section in that municipality ${ }^{2}$, except for some municipalities in which, due to its national importance, the candidate number one in the list is selected by the party leader being the other member of the list recruited with more or less autonomy by the local party structure.

For the first time, foreign citizens were able to vote and to be elected in the 1997 local elections ${ }^{3}$, Since then, citizens from EU countries can vote in local elections, as well as citizens from the Portuguese-speaking countries (after a two-year stay in Portugal), and foreigners from other countries (after a three-year stay in the country). However, only a small number of countries have met the reciprocity criteria. The number of registered citizens was low in each of the three elections that took place after the law had been adopted.

The new law on gender parity, approved in $2006^{4}$, will certainly increase the recruitment of more women for the Municipal Councils, which together with the possibility of part-time involvement in executive functions that the law already permits will help promote gender equality in local political leadership. However, it has to be made sure that the electoral system (the proportional closed-list system) is not replaced, for example, by an open-list system, and that other indirect factors also concur in that, as Borisyuk et al. (2007) indicate the UK case.

The measures intended to remove the barriers facing ethnic minority candidates and to increase their local political representation have not been explicitly taken. No evidence has been found about the existence of specific positive discrimination measures regarding ethnic minority participation in party lists in local elections, although no one can be prevented from being a member of a political party nor can they be expulsed from it due to their race (Law 2/2003, article 20).

Legal incompatibilities prevent different categories of citizens from standing for municipal elections (Duarte Silva, 1992). For example, the President of the Republic, Judges, Public Prosecutors, members of the National Electoral Commission, members of the police and armed forces, priests (active in the municipality) of any religion, tax department directors, municipal employees (in 
their own municipality), owners or managers of enterprises with on-going contracts concluded with the municipality, among other categories (Law 1/2001), cannot participate as candidates in municipal elections.

The term length, four years instead of three, as in the first three democratic municipal elections (1976, 1979, 1982), may affect the willingness of some professionals to run for election because the period such as this can limit reasonable ambitions in their professional career. On the other hand, in the case of 'non-permanent councillors' (or non-executive councillors), the relatively reduced amount of time required to fulfil their functions allows regular professional activity or even accumulation of other political roles at the national level, thus making this form of part-time active political participation possible. The status of council service, the perspectives for political career advancements, perceived personal costs and benefits, remuneration and the expected political tasks assigned to the Municipal Council members are also the factors affecting recruitment.

Finally, since 2006, the Municipal Council members in local government cannot be re-elected more than twice ( 3 consecutives terms or 12 years). This norm is expected to contribute to the renewal of the local political class ${ }^{5}$ in the 2009 election in which it will be applied for the first time. In fact, as Silva (2002) shows in her analysis of municipal elections between 1976 and 2001, there is an 'incumbency bias' in the case of Portugal, a phenomenon that reflects the tendency for an electoral advantage of those holding the Mayor's position (in all local elections there was re-election with more than $50 \%$ of the vote, and almost $70 \%$ in 1997 and 2001). This norm seeks to prevent political professionalisation, a risk that exists in the national parliament, as Freire (2002) says. It is likely to lead to the inclusion of a greater proportion of non-professional politicians, allowing local government to benefit from a wider set of personal and professional experiences while simultaneously avoiding political practices that first of all seek to guarantee the political survival of local councillors and only vaguely the local public interest.

This paper traces the key features of the Portuguese local political leadership model, including the rules that govern local political recruitment, and compares it to the dominant model in most European countries. The evidence corroborates our initial hypothesis of an overall trend towards convergence between the formal model of local political leadership and the "mayoral model" that tends to prevail in most parts of Europe, as well as a convergence with the basic norms and practices that govern local political recruitment. As in other European countries, despite the uniformity of municipal institutional forms across the country, political leadership and recruitment practices differ from municipality to municipality or from one electoral term to the next because political actors, mayors and 
councillors have sufficient room for manoeuvre to choose different courses of action between the points of reference defined in law.

New political initiatives were announced at the end of 2007 to reform the local political system, moving it towards a 'parliamentary system' and from proportional representation to the majority method in the election of the Municipal Council in order to have one-party executives which, among other effects, are expected to make political accountability more transparent from the elector's perspective, but certainly not yet from the aspect of control and scrutiny exercised by the Municipal Assembly. The proposed reform excludes the direct election of the Mayor, thereby being a divergence with the general trend in Europe. However, it reinforces the Mayor's individual powers inside the Municipal Council, which can be seen as a soft move towards the "mayoral model". Whether or not these institutional changes will continue and to what degree and how and to what extent they will influence local political leadership remains to be seen.

\section{Notes}

1 This proposal with substantial changes was adopted by the Parliament, Law 1/2001, 4 August. One of the arguments for the rejection of that change from direct to indirect election of the Municipal Council was that the number of municipalities, in which there was no overall majority in the Municipal Council, was very small and, therefore, in practice there was no relevant problem with that situation. It continues to be so. In fact, in the 2005 municipal election, in $91 \%$ (280 in a total of 308) of the municipalities there was an overall majority in the Municipal Council.

2 See, for example: PS (2003) - Socialist Party (Estatutos, 2003, “art. 41º, d); PSD (2006) Social Democratic Party (Estatutos, 2006, art. $53^{\circ}$, f) and art. $41^{\circ}$.

${ }^{3}$ Law 50/1996, 4 September changed the previous electoral law (Decret-law 701-B/76, 29 September 1976). This law applied the EU Directive $n^{\circ}$ 94/80/CE, 19 December about the right of any EU citizen to vote and to be elected in local elections in another EU country. This right was also extended to other foreign citizens according to specific conditions (reciprocity, etc.). Law 1/2001, 14 August. These two possibilities (to vote and to be elected) are only applied to citizens of those countries that also recognize the same right to the Portuguese citizens living there.

${ }^{4}$ Decret 52/X, April 2006 (called "Parity Law", was approved by the Parliament but vetoed by the President of the Republic). It proposed a minimum of $33.3 \%$ of each sex in the lists and the prohibition of those lists that did not observe this proportion. After the Presidential veto, the Socialist Party submitted a revised version, maintaining the $33.3 \%$ criteria, but with a new type of sanction (reductions in the state subvention for the electoral participation). This second version of the law was accepted by the President of the Republic (Law 3/2006, 21 August 2006). This quota criterion is not compulsory in small parishes ( $\leq 750$ inhabitants) and in small municipalities ( $\leq 7500$ inhabitants).

${ }^{5}$ Law 46/2005, 29 August. This restriction applies only to Mayors and to the Parish Council chairmen. After a four-year interruption, they will again be able to be elected. This legislation was criticized by the national association of municipalities, arguing that it affected political freedom and was unnecessary because $33 \%$ of the posts were occupied by first time elected members (ANMP, 2005), and criticized by several political parties as well. 


\section{References}

ANMP (2005) Boletim da ANMP, Associação Nacional dos Municípios Portugueses, pp. 135.

Bäck, H. (2005) 'The institutional setting of local political leadership and community involvement' in: Haus, M., Heinelt, H. \& Stewart, M. (Eds) (2004) Urban Governance and Democracy. Leadership and community involvement (London: Routledge), pp. 65-101.

Berg, R. \& Rao, N. (Eds) (2005) Transforming Local Political Leadership (New York: Palgrave).

Borisyuk, G., Rallings, C. \& Thrasher, M. (2007) Women in English local government, 19732003: getting selected, getting elected, Contemporary Politics, 13 (2), pp.181-199.

Borraz, O., \& John, P. (2004) The transformation of urban political leadership in Western Europe, International Journal of Urban and Regional Research, 28 (1), pp. 107-120.

Broussine, M. \& Fox, P. (2002) Rethinking leadership in local government: the place of 'feminine' styles in the modernised council, Local Government Studies, 28 (4), pp. 91-106.

Constituição da República Portuguesa - VII Revisão Constitucional (2005).

Copus, C. (2004) Directly elected mayors: a tonic for local governance or old wine in new bottles?, Local Government Studies, 30 (4), pp. 576-588.

Dahlerup, D. (2007) Electoral gender quotas: between equality of opportunity and equality of result, Representation, 43 (2), pp. 73-92.

Davidson-Schmich, L. (2006) Implementation of political party gender quotas. Evidence from the German Lander 1990-2000, Party Politics, 12 (2), pp. 211-232.

Denters, B. \& Rose, L. (2005) 'Towards local governance?' in: Denters, B. \& Rose, L. (Eds) Comparing Local Governance. Trends and developments (New York: Palgrave) pp. 246262.

Diário da Assembleia da República (several years).

Diário da República (several years).

Duarte Silva, A. (1992) As inelegibilidades nas eleições autárquicas. Estudos sobre a Jurisprudência do Tribunal Constitucional (Aequitas Editorial Notícias: Lisbon).

Fallend, F., Ignits, G. \& Swianiewicz, P. (2006) 'Divided loyalties? Mayors between party representation and local community interests' in: H. Bäck, H. Heinelt \& A. Magnier (Eds) The European Mayor Political Leaders in the Changing Context of Local Democracy. (Wiesbaden: VS Verlag für Sozialwissenschaften).

Fenwick, J., Elcock, H. \& McMillan, J. (2006) Leadership and management in UK local government: a role for elected mayors?, International Review of Administrative Sciences, 72(3), pp. 431-447.

Fernandes, A. T. (1993) Poder autárquico e poderes difusos, Revista da Faculdade de Letras da Universidade do Porto - Sociologia, 3, pp. 7-33.

Freire, A. (2002) A profissionalização política dos deputados portugueses, Revista da Faculdade de Letras da Universidade do Porto - Sociologia, 12, pp. 27-56.

Gabriel, O. \& Eisenmann, S. (2005) Germany: a new type of local government? , in: B. Denters \& L. Rose (Eds), Comparing Local Governance. Trends and developments (New York: Palgrave) pp. 119-138.

Geddes, M. (2006) Partnership and the limits to local governance in England: institutionalist analysis and neoliberalism, International Journal of Urban and Regional Research, 30(1), pp. 7697.

Geissel, B. \& Hust, E. (2005) Democratic mobilisation through quotas: experiences in India and Germany, Commonwealth \& Comparative Politics, 43 (2), pp. 222-244. 
Genieys, W., Ballart, X. \& Valarié, P. (2004) From 'great' leaders to building networks: the emergence of a new urban leadership in Southern Europe?, International Journal of Urban and Regional Research, 28 (1), pp. 183-200.

Gissendanner, S. (2004) Mayors, governance coalitions, and strategic capacity. Drawing lessons from Germany for theories of urban governance, Urban Affairs Review, 40 (1), pp. 44-77.

Goldsmith, M. (2002) Central control over local government - a Western European comparison, Local Government Studies, 28 (3), pp.91-112.

Goldsmith, M. \& Larsen, H. (2004) Local political leadership: Nordic Style, International Journal of Urban and Regional Research, 28 (1), pp. 121-133.

Hambleton, R. \& Sweeting, D. (2004) U.S. - Style leadership for English local government?, Public Administration Review, 64 (4), pp. 474-488.

Haus, M. \& Sweeting, D. (2006) 'Mayors, Citizens and Local Democracy' in: H. Bäck, H. Heinelt \& A. Magnier (Eds) The European Mayor Political Leaders in the Changing Context of Local Democracy (Wiesbaden: VS Verlag für Sozialwissenschaften).

Hazan, R. \& Rahat, G. (2006) Candidate selection: methods and consequences, in: R. Katz \& W. Crotty (Eds) Handbook of Party Politics (London: Sage), pp. 109-121.

Holli, A., Luhtakallio, E. \& Raevaara, E. (2006) Quota trouble: talking about gender quota in finnish local politics, International Feminist Journal of Politics, 8 (2), pp.169-193.

Johansson, V. (2006) Gendered roads to mayorship in different welfare states, in: H. Bäck, H. Heinelt \& A. Magnier (Eds) The European Mayor Political Leaders in the Changing Context of Local Democracy. (Wiesbaden: VS Verlag für Sozialwissenschaften).

Katz, R. \& Mair, P. (1994) How parties organize. Change and adaptation in Party organizations in Western democracies (London: Sage)

Kjaer, U. (2007) The decreasing number of candidates at Danish local elections: local democracy in crisis?, Local Government Studies, 33 (2), pp. 195-213.

Kolk, H. (2007) Local electoral systems in Western Europe, Local Government Studies, vol. 33(2), pp.159-180.

Leach, S., Hartley, J., Lowndes, V., Wilson, D. \& Downe, J. (2005) Local political leadership in England and Wales (York: Joseph Rowntree Foundation).

Magre, J. \& Bertrana, X. (2007) Exploring the limits of institutional change: the direct election of mayors in Western Europe, Local Government Studies, 33 (2), pp. 181-194.

Martinussen, P. (2004) Majority rule in consensual democracies: explaining political influence in Norwegian local councils, Local Government Studies, 30(3), pp. 303-330.

Meadowcroft, J. (2001) Political recruitment and local representation: the case of liberal democrat councillors, Local Government Studies, 27 (1), pp. 17-36.

Mitchell, J. \& Bradbury, J. (2004) Political recruitment and the 2003 Scotish and Welsh Elections: candidate selection, positive discrimination and party adaptation, Representation, 40 (4), pp. 289-302.

Norris, P. (2006) Recruitment, in: Katz, R. \& Crotty, W. (Eds) Handbook of Party Politics (London: Sage), pp. 89-108.

PSD (2006) Estatutos - Partido Social-Democrata.

PS (2003) Estatutos - Partido Socialista.

Rose, L. \& Stahlberg, K. (2005) The Nordic Countries: still the 'promised land'?, in: B. Denters \& L. Rose (Eds) Comparing Local Governance. Trends and developments (New York: Palgrave), pp. 83-99.

Saint-Maurice, A.; Batista, J., Pinho, A. (1997) Caracterização Sociográfica das Mulheres Eleitas para as Autarquias Locais 1993. Relatório final (Lisbon: Secretariado Técnico dos Assuntos para o Processo Eleitoral). 
Silva, E. G. (2002) Barreiras à entrada no mercado político - as eleições autárquicas portuguesas, Revista da Faculdade de Letras da Universidade do Porto - Sociologia, 12, pp. 145-154.

Stone, C. (2005) Institutions count but resources decide. American mayors and the limits of formal structure, in: R. Berg \& N. Rao (Eds) Transforming Local Political Leadership, (New York: Palgrave), pp. 180-211.

Threlfall, M. (2007) Explaining gender parity representation in Spain: the internal dynamics of parties, West European Politics, 30 (5), pp. 1068-1095.

Vogelsang-Coombs, V. (2007) Mayoral leadership and facilitative governance, The American Review of Public Administration, 37 (2), pp.198-225.

Wheeler, P. (2006) Political recruitment: how local parties recruit councillors (York: Joseph Rowntree Foundation).

Wollmann, H. (2004) Urban leadership and German local politics: the rise, role and performance of the directly elected (chief executive) mayor, International Journal of Urban and Regional Research, 28 (1), pp. 150-165.

Wollmann, H. (2004) Local government reforms in Great Britain, Sweden, Germany and France: Between multi-function and single-purpose organisations. Local Government Studies, 30 (4), pp. 639-665. 